SOUZA, LGS; FERREIRA, RLF; ARAÚJO NETO, SE; SILVA, NM; UCHÔA, TL; ALMEIDA, WA. 2020. Chicory yield influenced by seedling quality and growing environment. Horticultura Brasileira 38: 224-229. DOI - http://dx.doi.org/10.1590/S0102-053620200216

\title{
Chicory yield influenced by seedling quality and growing environment
}

\author{
Luís Gustavo de S e Souza ${ }^{1 * \mathbb{D}}$; Regina Lúcia F Ferreira ${ }^{1} \mathbb{D}$; Sebastião Elviro de Araújo Neto ${ }^{1} \mathbb{D}$; Nilciléia $M$ \\ da Silva ${ }^{1} \mathbb{D}$; Thays $L$ Uchôa ${ }^{1} \mathbb{D} ;$ Waldiane A de Almeida ${ }^{1} \mathbb{D}$
}

${ }^{1}$ Universidade Federal do Acre (UFAC), Rio Branco-AC, Brasil; gustavo_souza_fj@hotmail.com; reginalff@yahoo.com.br; selviro2000@ yahoo.com.br; nilcileia-ac@hotmail.com; thays_uchoa@yahoo.com.br; waldianearaujo@hotmail.com; *author for correspondence

\section{ABSTRACT}

The objective of this work was to evaluate the quality of chicory seedlings in organic substrata and their influence on yield and commercial yield in a protected environment and under direct sunlight. Seedling and field production experiments were conducted in a randomized block design with four blocks. In the first experiment, seedlings were produced on substrata by alternating the conditioner: 1) dry coconut fiber + blend (soil, organic compost, charcoal); 2) carbonized rice husk + blend; 3 ) crushed ouricuri stem + blend; 4) decomposed kapok stem + blend and 5) commercial substratum. Sufficient seedlings were produced for the evaluations and transplantation. In the field phase, two experiments were evaluated, one in a protected environment and another under direct sunlight. The commercial and ouricuri substrata produced seedlings with the same quality and biomass index, but above to the others. The yield $\left(0.89 \mathrm{~kg} \mathrm{~m}^{-2}\right)$ and commercial yield $\left(68.29\right.$ packs $\left.\mathrm{m}^{-2}\right)$ in the protected environment are not affected by seedling quality. In the direct sunlight cultivation, the yield is higher when using seedlings produced with the commercial $\left(0.75 \mathrm{~kg} \mathrm{~m}^{-2}\right)$, ouricuri $\left(1.07 \mathrm{~kg} \mathrm{~m}^{-2}\right)$, or kapok substrata $\left(0.74 \mathrm{~kg} \mathrm{~m}^{-2}\right)$.

Keywords: Eryngium foetidum, organic agriculture, alternative substratum, protected cultivation, organic residues.

\section{RESUMO}

Produção da Chicória da Amazônia influenciada pela qualidade da muda e ambiente de cultivo

O objetivo deste trabalho foi avaliar a qualidade de mudas de chicória em substratos orgânicos e sua influência sobre a produtividade e rendimento comercial em cultivo protegido e pleno sol. Foram conduzidos experimentos na fase de mudas e de produção em campo, instalados em delineamento em blocos casualizados, com quatro blocos. No primeiro experimento, mudas foram produzidas em substratos alternando o condicionador: 1) fibra de coco seco + mistura (solo, composto orgânico, carvão vegetal); 2) casca de arroz carbonizada + mistura; 3) caule triturado de ouricuri + mistura; 4) caule decomposto de sumaúma + mistura e 5) substrato comercial. Produziu-se mudas suficientes para avaliações e transplantio. Na fase de campo, avaliaram-se dois experimentos, um em ambiente protegido e outro a pleno sol. Os substratos, comercial e Ouricuri, produziram mudas com o mesmo índice de qualidade e biomassa, porém, superiores aos demais. A produtividade $\left(0,89 \mathrm{~kg} \mathrm{~m}^{-2}\right)$ e o rendimento comercial $\left(68,29\right.$ maços $\left.\mathrm{m}^{-2}\right)$ em ambiente protegido não são afetados pela qualidade da muda. No cultivo a pleno sol, a produtividade é maior quando se utiliza mudas produzidas com os substratos comercial $\left(0,75 \mathrm{~kg} \mathrm{~m}^{-2}\right)$ ou ouricuri $\left(1,07 \mathrm{~kg} \mathrm{~m}^{-2}\right)$ ou sumaúma $\left(0,74 \mathrm{~kg} \mathrm{~m}^{-2}\right)$.

Palavras-chave: Eryngium foetidum, agricultura orgânica, substratos alternativos, cultivo protegido, resíduos orgânicos.

\section{Received on May 30, 2019; accepted on March 26, 2020}

$\mathrm{C}$ hicory (Eryngium foetidum) is a plant species belonging to the Apiaceae family, native to tropical regions of Central and South America (Morales-Payán et al., 2013). Classified as non-conventional vegetable, it is consumed as condiment (Madeira et al., 2013) and for medicinal purposes, as it contains aliphatic and aromatic compounds, such as eryngial, with anti-inflammatory, analgesic, and antioxidant potential (Singh et al., 2013; Thomas et al., 2017).

In spite of its great importance as a non-conventional vegetable, studies related to seedling production and cultivation of chicory are still scarce given the low technological level and the few technical recommendations to the crop, resulting in low production efficiency, high commercial value, and little availability.

However, organic farming appears as an alternative for chicory production since it presents low production cost, rusticity, and easy management, although this system lacks alternative technologies for seedling and field production.

Regarding seedling production, there is no available material with all the required characteristics for plant development, thus justifying the need for research (Cerqueira et al., 2015) aiming at alternative substrata that fit the economic needs of the producer and the phytotechnical demands of the crop (Ferraz et al., 2014; Ferreira et al., 2017).

The greater control of production factors in the cultivation environment can favor plant development even when using lower-quality seedlings, such as those produced with substrata based on coconut fiber, rice husk, and kapok stem, with a similar development to the seedlings produced in substratum based on palm stipe (Simões et al., 2015). 
Vegetable cultivation in protected environments allows the production in the off-season period by reducing the attack by plagues and diseases, as well as weather adversities (radiation reduction and protection against rainfall excess) that affect the crop under direct sunlight (Reis et al., 2012).

Aiming at contributing to the elaboration of cultivation techniques, this work aimed to evaluate the quality of chicory seedlings in organic substrata and their influence on the yield and commercial yield in protected cultivation and under direct sunlight.

\section{MATERIAL AND METHODS}

The experiment was performed in Rio Branco-AC, at the Seridó Archaeological Site (9०53'11'S; 67'49'9"W; $170 \mathrm{~m}$ altitude), in the period from March to June 2017, lasting for 94 days. The climate of the region is hot and wet, of the Am type, according to the classification by Köppen, with a mean temperature of $25.4^{\circ} \mathrm{C}$, relative air humidity of 88.4 , and annual rainfall of $752 \mathrm{~mm}$ (INMET, 2017).

The soil is classified as a YELLOW ARGISOL, presenting as chemical attributes in the $0-20 \mathrm{~cm}$ layer: $\mathrm{pH}=6.4$; O.M. $=30.0 \mathrm{~g} \mathrm{dm}^{-3} ; \mathrm{P}=15 \mathrm{mg} \mathrm{dm}^{-3} ; \mathrm{K}=$ $1.5 \mathrm{mmol}_{\mathrm{c}} \mathrm{dm}^{-3} ; \mathrm{Ca}=62.0 \mathrm{mmol}_{\mathrm{c}} \mathrm{dm}^{-3}$; $\mathrm{Mg}=19.0 \mathrm{mmol}_{\mathrm{c}} \mathrm{dm}^{-3} ; \mathrm{Al}=1.0 \mathrm{mmol}_{\mathrm{c}}$ $\mathrm{dm}^{-3} ; \mathrm{H}+\mathrm{Al}=20.0 \mathrm{mmol}_{\mathrm{c}} \mathrm{dm}^{-3} ; \mathrm{SB}=$ $82.5 \mathrm{mmol}_{\mathrm{c}} \mathrm{dm}^{-3} ; \mathrm{CEC}=102.5 \mathrm{mmol}_{\mathrm{c}}$ $\mathrm{dm}^{-3} ; \mathrm{V}=80.4 \%$.

The experiments were performed in the phases of seedling production and field production of chicory.

Chicory seedling production and quality evaluation

An experiment was performed in which the substrata composed of organic residues were evaluated. The experimental design was set up in randomized blocks, with five treatments, four replications, and 10 seedlings per experimental unit. The substrata conditioner was altered in the treatments, as follows: 1) dry coconut fiber + blend (soil, organic compost, crushed vegetable charcoal); 2) carbonized rice husk + blend; 3) crushed ouricuri stem (Attalea phalerata) + blend; 4) decomposed kapok stem (Ceiba pentandra) + blend, and 5) commercial substratum, as control.

The substrata used for seedling production, except the commercial substratum, were composed of $30 \%$ soil (0-5 layer); $30 \%$ organic compost (based on Brachiaria decumbens); $30 \%$ conditioner (treatment); 10\% crushed vegetal charcoal; $1.0 \mathrm{~kg} \mathrm{~m}^{-3}$ of dolomitic limestone; $1.5 \mathrm{~kg} \mathrm{~m}^{-3}$ of natural thermophosphate, and $1.0 \mathrm{~kg}$ $\mathrm{m}^{-3}$ of potassium sulfate. In all substrata, the chemical and physical analyses exhibited in Table 1 were performed.

The chicory seeds were obtained from previous cultivations in a uniform population. The seedlings were produced in expanded polystyrene trays with 128 cells. After the emergence, the thinning and pricking out of the seedlings was performed, allowing only one seedling per cell.

The seedlings were maintained in a plant nursery until presenting from 4-6 leaves, 52 days after sowing, when the following evaluations were performed in the plants from each parcel: leaf number count; seedling height $(\mathrm{cm})$; base diameter ( $\mathrm{mm})$; shoot dry mass $(\mathrm{g})$, and root dry mass (g), measured in a digital balance with a precision of 0.05 $\mathrm{mg}$ after drying in a forced-air oven at $65^{\circ} \mathrm{C}$, until reaching constant weight. Root dry mass was obtained by washing it with water and separating it from the shoot part.

The seedling quality index (SQI), proposed by Dickson et al. (1960), was calculated through the following mathematical equation: $\mathrm{SQI}=[\mathrm{TDM}] /$ $[(\mathrm{PH} / \mathrm{BD})+(\mathrm{SDM} / \mathrm{RDM})]$. In which: $\mathrm{SQI}=$ Seedling quality index; TDM = Total dry mass $(\mathrm{g}) ; \mathrm{PH}=$ Plant height $(\mathrm{cm}) ; \mathrm{BD}=$ Base diameter $(\mathrm{mm})$; SDM $=$ Shoot dry mass (g); RDM = Root dry mass $(\mathrm{g})$.

After data tabulation, the normality of errors and the homogeneity of variances were verified, proceeding to the analysis of variance by the $F$ test. Afterward, the comparison of means was performed by Tukey's test at a 5\% significance level.

Chicory production in a protected environment under direct sunlight

In this phase, two independent experiments were performed, both in a randomized block design with four replications, one in a protected environment and the other under direct sunlight. The treatments in each environment consisted of seedlings originated from the already evaluated substrata: 1) dry coconut fiber + blend; 2) carbonized rice husk + blend; 3) crushed ouricuri stem + blend; 4) decomposed kapok stem + blend, and 5) commercial substratum, as control. Each experimental unit was composed of 20 plants. It is worth noting that enough seedlings were produced for the evaluations and transplantation.

The protected environment was a gable greenhouse with open laterals, covered with 100-Micra transparent film, with 48\% luminosity retention, measured with a light meter.

In the two experiments, seedlings were transplanted in $15 \times 15 \mathrm{~cm}$ spacing to plant beds with $1.2 \mathrm{~m}$ width, $15 \mathrm{~cm}$ height, and $30 \mathrm{~m}$ length, fertilized with $6.25 \mathrm{~L} \mathrm{~m}^{-2}$ of organic compost and $4.16 \mathrm{~L} \mathrm{~m}^{-2}$ of vegetal biofertilizer. The organic compost and the biofertilizer were produced based on Brachiaria decumbens.

Daily irrigation was performed along with the cutting of the inflorescences. No topdressing fertilization was performed, and there was no need for phytosanitary and weed control.

Plants were harvested 42 days after transplantation, when nine out of the twenty plants in each experimental unit were evaluated, eliminating the border plants. The evaluations performed in this stage were fresh and dry (drying at $65^{\circ} \mathrm{C}$ until constant weight) shoot dry mass (g); yield $\left(\mathrm{kg} \mathrm{m}^{-2}\right)$, and commercial yield (packs $\mathrm{m}^{-2}$ ). Leaf length was also verified in three plants per plot, with the aid of a millimeter ruler. Afterward, the plants were classified by frequency distribution in class $1(2.50-9.62 \mathrm{~cm})$, class $2(9.63-$ $16.76 \mathrm{~cm})$, and class $3(16.77-23.90 \mathrm{~cm})$ according to the percentage of leaves per class, with classes 2 and 3 being considered as commercial.

Once obtaining the data, the normality of errors and homogeneity of variances were verified, proceeding to the analysis of variance by the $\mathrm{F}$ test. A joint analysis of the experiments was performed (protected environment and direct sunlight cultivation) since the 
mean squares of the residues were below means comparison test was applied at $5 \%$ significance level.

\section{RESULTS AND DISCUSSION}

\section{Production of chicory seedlings and quality evaluation}

The $\mathrm{F}$ test was significant for number of leaves, shoot dry mass, root dry mass, total dry mass, and seedling quality index (SQI). The ouricuri and commercial substrata presented the best responses in all variables (Table 2).

The highest accumulation of total dry matter (94\%) observed in the commercial and ouricuri substrata (Table 2) is the result of an adequate nutritional balance and $\mathrm{pH}$ in the substratum (Table 1), which may have provided to the plant a better absorption and conversion in dry matter (Silva \& Queiroz, 2014). The adequate supply of nutrients in the production of vegetables, from the seedling stage until harvest, allows the full development and expression of the maximum plant potential (Araújo et al., 2012).

The substratum based on kapok stem, rice husk, and coconut fiber presented 7 (Banzatto \& Kronka, 2018). Tukey's

SQI below those of the ouricuri and commercial substrata, probably due to the low nutrient availability, attributed to the high $\mathrm{pH}$ values (Table 1) above 6.0 and 7.0 recommended by Kämpf (2000). Although presenting a similar number of leaves to the ouricuri and commercial substrata, the kapok and rice husk substrata did not produce seedlings with high-quality indices (Table 2).

With a $\mathrm{pH}$ above 7.0 , there is already a reduction in the availability of phosphorus (Sousa et al., 2007), which is an important element in the development of the root system and formation of dry matter in the plants. When in a situation of phosphorus deficiency, there is a reduction in the growth of young plants (Taiz \& Zeiger, 2013), such as observed in the coconut fiber, rice husk, and kapok-based substrata, which obtained $\mathrm{pH}$ values above the recommended.

High $\mathrm{K}$ concentrations in the medium may favor its absorption as well as reduce the absorption of $\mathrm{Ca}$ and $\mathrm{Mg}$ (Kano et al., 2010; Araújo et al., 2012; Zanfirov et al., 2012). In the substrata with coconut fiber and rice husk (Table 1), there was a high potassium content, which may have inhibited the absorption of $\mathrm{Ca}$ and $\mathrm{Mg}$, thus influencing so that

Table 1. Chemical and physical analysis of substrata consisting of organic residues. Campinas, Instituto Campineiro de Análise de Solo e Adubo, 2017.

\begin{tabular}{|c|c|c|c|c|c|c|}
\hline \multirow{2}{*}{ Substrata } & pH & $\mathbf{P}$ & $\mathbf{K}$ & $\mathrm{Ca}$ & Mg & $\mathbf{S}$ \\
\hline & \multicolumn{5}{|c|}{$\left(\mathrm{mg} \mathrm{L}^{-1}\right)$} & \\
\hline Coconut f. ${ }^{1}$ & 7.4 & 4.1 & 274.0 & 33.9 & 19.4 & 108.0 \\
\hline $\mathrm{CRH}^{2}$ & 7.5 & 6.6 & 194.0 & 38.9 & 25.3 & 119.0 \\
\hline Ouricuri ${ }^{3}$ & 6.5 & 6.6 & 176.0 & 45.1 & 34.2 & 129.0 \\
\hline Kapok $^{4}$ & 8.1 & 2.5 & 148.0 & 78.6 & 26.8 & 92.2 \\
\hline \multirow[t]{3}{*}{ Commercial $^{5}$} & 5.6 & 2.1 & 112.0 & 122.0 & 44.8 & 134.0 \\
\hline & B & $\mathbf{F e}$ & \multirow{2}{*}{$\begin{array}{c}\mathrm{Ad}^{6} \\
\left(\mathrm{~kg} \mathrm{~m}^{-3}\right)\end{array}$} & \multirow{2}{*}{$\begin{array}{c}\text { WRC }^{7} \\
(\%)\end{array}$} & \multirow{2}{*}{$\begin{array}{c}\text { EC }^{8} \\
\left(\text { Mili Scm }^{-1}\right)\end{array}$} & \\
\hline & & & & & & \\
\hline Coconut f. ${ }^{1}$ & 0.1 & 2.5 & 589.9 & 85.7 & 0.614 & \\
\hline $\mathrm{CRH}^{2}$ & 0.2 & 1.4 & 720.6 & 86.8 & 0.604 & \\
\hline Ouricuri ${ }^{3}$ & 0.3 & 2.0 & 779.3 & 84.4 & 0.457 & \\
\hline Kapok $^{4}$ & 0.1 & 0.9 & 742.0 & 96.9 & 0.453 & \\
\hline Commercial $^{5}$ & 0.1 & 0.4 & 269.0 & 249.4 & 0.639 & \\
\hline
\end{tabular}

${ }^{1}$ Coconut fiber + blend ( $30 \%$ organic compost, $30 \%$ soil, $10 \%$ charcoal, $1.0 \mathrm{~kg} \mathrm{~m}^{-3}$ dolomitic limestone, $1.0 \mathrm{~kg} \mathrm{~m}^{-3}$ potassium sulphate and $1.5 \mathrm{~kg} \mathrm{~m}^{-3}$ of natural thermophosphate); ${ }^{2} \mathrm{CRH}$ (carbonized rice husk) + blend; ${ }^{3}$ Ouricuri + blend; ${ }^{4}$ Kapok + blend; ${ }^{5}$ Commercial substratum. ${ }^{6} \mathrm{Ad}=$ apparent density (dry basis); ${ }^{7} \mathrm{WRC}=$ water retention capacity; ${ }^{8} \mathrm{EC}=$ Electrical conductivity. these treatments presented seedlings with lower SQI.

Alternative substrata, although originated from distinct materials, present similar physical characteristics (Table 1). The particle size and the arrangement influence the adequate water retention, good aeration, and low resistance to penetration by the roots (Zorzeto et al., 2014; Brito et al., 2017), assuring the physical quality in seedling production. Although the commercial substratum presented high water retention capacity, its density was lower, thus ensuring greater porosity, better drainage, and lower physical restriction to plant growth (Maggioni et al., 2014).

Chicory production in a protected environment and under direct sunlight

The interaction was significant for the fresh and dry mass, yield, and commercial yield variables. For these variables, direct sunlight cultivation was superior when using seedlings produced with the ouricuri and kapok substrata. In the protected environment, there was no significant difference regarding the seedlings originated from distinct substrata (Table 3).

As observed in the seedling phase, the coconut fiber, kapok stem, and carbonized rice husk conditioners produced seedlings of lower quality (Table 2). Nevertheless, the seedlings produced with these substrata, when cultivated in a protected environment, presented no difference to the remainder for fresh and dry mass, yield, and commercial yield. This occurred since, besides the plant capacity in recovering during its development, the soil in an organic system and protected environment does not receive rainfall and, therefore, preserves its organic matter under more favorable weather conditions (Larcher, 2000; Oliveira et al., 2010; Silva et al., 2015).

The cultivation in a protected environment exerted greater influence in the increase of fresh mass and yield values due to the reduction by $48.5 \%$ in luminosity, verifying that chicory develops better in this environment, such as observed by Moniruzzaman et al. (2009), when cultivating chicory under 
a $50 \%$ shading and thus optimizing the yield.

According to Ferreira et al. (2009) and Hirata \& Hirata (2015), the conditions of the protected environment increase the number of leaves, the production of shoot fresh mass, and produce more hydrated and soft plants. In the cultivation of leaf vegetables, such as lettuce and watercress (Rorippa nasturtium-aquaticum), the yield increases by $55 \%$ and $59 \%$, respectively, compared

Table 2. Number of leaves (NL), shoot dry mass (SDM), root dry mass (RDM), total dry mass (TDM), and seedling quality index (SQI) of chicory produced with organic residues. Rio Branco, UFAC, 2017.

\begin{tabular}{llllll}
\hline \multirow{2}{*}{ Substrata } & \multirow{2}{*}{ NL } & \multicolumn{1}{c}{ SDM } & RDM & TDM & \multirow{2}{*}{ SQI } \\
\cline { 3 - 5 } & & \multicolumn{3}{c}{ (g seedling $\left.^{-1}\right)$} \\
Commercial & $5.53 \mathrm{a}$ & $0.052 \mathrm{a}$ & $0.044 \mathrm{a}$ & $0.096 \mathrm{a}$ & $0.029 \mathrm{a}$ \\
Ouricuri & $5.38 \mathrm{ab}$ & $0.043 \mathrm{ab}$ & $0.032 \mathrm{ab}$ & $0.075 \mathrm{ab}$ & $0.020 \mathrm{ab}$ \\
Coconut fiber & $4.85 \mathrm{~b}$ & $0.029 \mathrm{bc}$ & $0.025 \mathrm{bc}$ & $0.054 \mathrm{bc}$ & $0.017 \mathrm{bc}$ \\
Kapok & $5.25 \mathrm{ab}$ & $0.029 \mathrm{bc}$ & $0.016 \mathrm{c}$ & $0.045 \mathrm{bc}$ & $0.011 \mathrm{c}$ \\
CHR & $5.00 \mathrm{ab}$ & $0.020 \mathrm{c}$ & $0.016 \mathrm{c}$ & $0.036 \mathrm{c}$ & $0.013 \mathrm{c}$ \\
\hline $\mathrm{CV}(\%)$ & 3.20 & 23.81 & 11.82 & 11.09 & 10.18 \\
\hline
\end{tabular}

Means followed by same letters do not differ $(\mathrm{p}>0.05)$ from each other by Tukey's test.

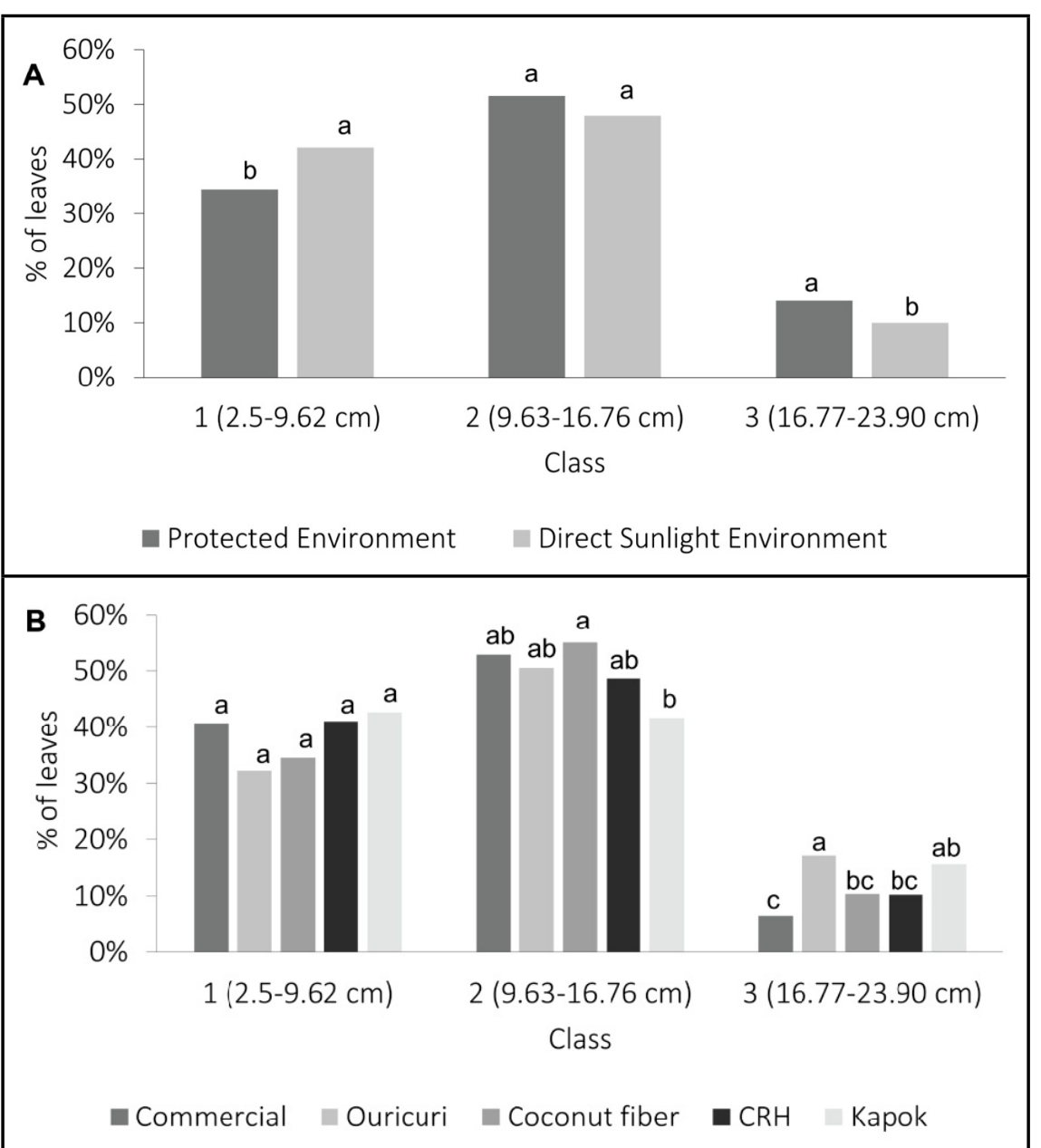

Figure 1. Classification by length (cm) of chicory leaves, in classes 1, 2, and 3, produced in a protected environment and under direct sunlight (A), with seedlings originated from substrata based on organic residues (B). Means followed by same letters do not differ ( $p>0.05)$ from each other by Tukey's test. Rio Branco, UFAC, 2017.

to direct sunlight cultivation, which was also observed for chicory production (Table 3).

Fresh mass and yield are important variables for leaf vegetables such as chicory, representing the part of commercial interest. In a protected environment, chicory yield was superior by $18.69 \%$ compared to direct sunlight cultivation. The yield, however, was below $(\mathrm{p}<0.05)$ the obtained by Gomes et al. (2013), also in a protected environment in the conditions of BelémPA, with mean values of $1.49 \mathrm{~kg} \mathrm{~m}^{-2}$.

The cultivation in a protected environment presented 68.42 packs $\mathrm{m}^{-2}$ mean commercial yield, whereas under direct sunlight it was 55.39 packs $\mathrm{m}^{-2}$, with emphasis on plants obtained from the ouricuri (77.77 packs $\mathrm{m}^{-2}$ ), commercial (62.18 packs $\mathrm{m}^{-2}$ ) and kapok substrata (61.96 packs $\mathrm{m}^{-2}$ ). These substrata also increased the yields of lettuce in a research performed by Simões et al. (2015).

The reduction in light intensity influences the morphological characteristics of the plant, which, by its adaptation capacity, uses the photoassimilates for the development of the leaf area with the increase in the photosynthetic capacity (Colombo et al., 2015). The increments in dry mass and yield, according to Guerra et al. (2017), result from the internal conditions of the protected environment (reduction of temperature and luminosity and increase in air relative humidity), creating a favorable microclimate to the photosynthetic activity by increasing the inflow of $\mathrm{CO}_{2}$ and reducing plant transpiration through the greater time of stomatal opening.

The classification of chicory leaves presented an isolated effect for environments and substrata. The leaves from classes 2 and 3, with a greater proportion in the protected environment (Figure 1), are at the point of harvest due to presenting greater size. The plants cultivated under direct sunlight presented slower growth than those under protected cultivation, thus the greater proportion of small leaves.

In the protected environment the leaves reached commercial size (classes 2 and 3 ) precociously, and the difference 
Table 3. Total fresh (TFM) and dry mass (TDM), yield, and commercial yield of chicory produced in a protected environment and under direct sunlight with seedlings originated from substrata based on organic residues. Rio Branco, UFAC, 2017.

\begin{tabular}{|c|c|c|c|c|c|c|c|c|}
\hline \multirow{2}{*}{ Substrata } & \multicolumn{2}{|c|}{ TFM (g plant $\left.{ }^{-1}\right)$} & \multicolumn{2}{|c|}{ TDM (g plant $\left.{ }^{-1}\right)$} & \multicolumn{2}{|c|}{ Yield $\left(\mathrm{kg} \mathrm{m}^{-2}\right)$} & \multicolumn{2}{|c|}{ Commercial yield (pakes $\mathrm{m}^{-2}$ ) } \\
\hline & $\mathbf{A P 1}$ & PS $^{2}$ & $\mathbf{A P ^ { 1 }}$ & PS $^{2}$ & $\mathbf{A} \mathbf{P}^{1}$ & PS $^{2}$ & $\mathbf{A P} \mathbf{P}^{1}$ & PS $^{2}$ \\
\hline Commercial & $19.63 \mathrm{Aa}$ & $16.75 \mathrm{Aab}$ & $3.20 \mathrm{Aa}$ & $2.75 \mathrm{Aab}$ & $0.87 \mathrm{Aa}$ & $0.75 \mathrm{Aab}$ & $67.08 \mathrm{Aa}$ & $57.28 \mathrm{Aab}$ \\
\hline Ouricuri & $21.38 \mathrm{Aa}$ & $24.13 \mathrm{Aa}$ & $3.14 \mathrm{Aa}$ & $3.59 \mathrm{Aa}$ & $0.95 \mathrm{Aa}$ & $1.07 \mathrm{Aa}$ & $73.05 \mathrm{Aa}$ & $82.48 \mathrm{Aa}$ \\
\hline Coconut fiber & $18.13 \mathrm{Aa}$ & $9.38 \mathrm{Bc}$ & $2.76 \mathrm{Aa}$ & $1.48 \mathrm{Bc}$ & $0.81 \mathrm{Aa}$ & $0.42 \mathrm{Bc}$ & $61.98 \mathrm{Aa}$ & $32.08 \mathrm{Bc}$ \\
\hline $\mathrm{CRH}$ & $21.13 \mathrm{Aa}$ & 14.13 Bbc & $2.98 \mathrm{Aa}$ & $2.53 \mathrm{Ab}$ & $0.94 \mathrm{Aa}$ & $0.63 \mathrm{Bbc}$ & $72.23 \mathrm{Aa}$ & $48.30 \mathrm{Bbc}$ \\
\hline Kapok & $19.63 \mathrm{Aa}$ & $16.63 \mathrm{Aab}$ & $2.78 \mathrm{Aa}$ & $2.51 \mathrm{Ab}$ & $0.87 \mathrm{Aa}$ & $0.74 \mathrm{Aab}$ & $67.10 \mathrm{Aa}$ & $56.83 \mathrm{Aab}$ \\
\hline $\mathrm{CV}(\%)$ & \multicolumn{2}{|c|}{7.56} & \multicolumn{2}{|c|}{12.28} & \multicolumn{2}{|c|}{10.88} & \multicolumn{2}{|c|}{10.88} \\
\hline
\end{tabular}

${ }^{1}$ Protected environment. ${ }^{2}$ Direct sunlight. Means followed by same uppercase letters in the row and lowercase in the column do not differ $(p>0.05)$ from each other by Tukey's test.

of $28.9 \%$ of leaves in relation to direct sunlight cultivation. The microclimate created by the protection of the plastic favors the development and precocity of leafy vegetables, such as observed by Araújo et al. (2010) for lettuce, which anticipated harvest in eight days.

The beneficial effect of the protected environment on leaf size increase was also verified by Moniruzzaman et al. (2009), obtaining chicory leaves with an average length of $20.75 \mathrm{~cm}$ when cultivated with $50 \%$ light restriction.

The plants originated from the ouricuri and kapok substrata produced a greater proportion of class 3 leaves (Figure 1). The leaves of these plants reached more rapidly the desirable size for commercialization.

The commercial substratum, although presenting superiority in the production variables (Table 3 ), had most of its leaves belonging to classes 1 and 2, probably for presenting a greater number of leaves to the detriment of their size.

The commercial and ouricuri substrata produce leaves with the same quality index and biomass, and above those of the remaining substrata. The yield $\left(0.89 \mathrm{~kg} \mathrm{~m}^{-2}\right)$ and commercial yield $\left(68.29\right.$ packs $\left.\mathrm{m}^{-2}\right)$ in the protected environment were not affected by seedling quality. In the direct sunlight cultivation, the yield is higher when using seedlings produced with the commercial $\left(0.75 \mathrm{~kg} \mathrm{~m}^{-2}\right)$, ouricuri $\left(1.07 \mathrm{~kg} \mathrm{~m}^{-2}\right)$, or kapok substrata $(0.74$ $\mathrm{kg} \mathrm{m}^{-2}$ ), not differing from the protected environment. Therefore, any of these substrata and cultivation environments are recommended.

\section{ACKNOWLEDGMENTS}

This work was performed with the support of the Coordination for the Improvement of Higher Education Personnel, Brazil (CAPES), Financing Code 001.

\section{REFERENCES}

ARAÚJO, HP; QUADROS, BR; CARDOSO, AII; CORREA, CV. 2012. Doses de potássio em cobertura na cultura da abóbora. Pesquisa Agropecuária Tropical 42: 469-475.

ARAÚJO, ST; FIDELES FILHO, J; KUMAR, KK; RAO, TVR. 2010. Crescimento da alface americana em função dos ambientes, épocas e graus-dias. Revista Brasileira de Ciências Agrárias 5: 441-449.

BANZATTO, DA; KRONKA, SN. 2018. Experimentação agrícola. Jaboticabal: Funep. 237p.

BRITO, PSL; CAVALCANTE, MZB; AMARAL, GC; SILVA, AA; AVELINO, RC. 2017. Reutilização de resíduos regionais como substratos na produção de mudas de cultivares de alface a partir de sementes com e sem peletização. Revista de la Facultad de Agronomía 116: 51-61.

CERQUEIRA, FB; FREITAS, GA; MACIEL, CJ; CARNEIRO, JSS; LEITE, RC. 2015. Produção de mudas de tomate cv. Santa Cruz em diferentes substratos. Journal of Bioenergy and Food Science 2: 39-45.

COLOMBO, JN; PUiATti, M; AltoÉ, LM; HADDADE, IR; SANT'ANA, RC. 2015. Efeito de diferentes materiais de sombreamento sobre a área foliar de plantas de taioba. Cadernos de Agroecologia 10 (CD-ROM).

DICKSON, A; LEAF, AL; HOSNER, JF. 1960. Quality appraisal of white spruce and white pine seedling stock in nurseries. Forestry Chronicle 36: 10-13.

FERRAZ, PA; MENDES, R; ARAÚJO NETO, SE; FERREIRA, RLF. 2014. Produção de mudas orgânicas de bertalha em diferentes substratos.
Enciclopédia Biosfera 10: 24-49.

FERREIRA, RLF.ARAÚJO NETO, SE; SILVA, SS; ABUD, EA; REZENDE, MIFL; KUSDRA, JF. 2009. Combinações entre cultivares, ambientes, preparo e cobertura do solo nas características agronômicas de alface. Horticultura Brasileira 27: 383-388.

FERREIRA, RLF; ARAÚJO NETO, SE; ALVES, GKEB; SIMÕES, AC; BOLDT, RH. 2017. Qualidade de mudas e produtividade de rúcula em função de condicionadores de substratos. Agropecuária Científica no Semiárido 13: 179-186.

GOMES, RF; SILVA, JP; GUSMÃO, SAL; SOUZA, GT. 2013. Produção de chicória da Amazônia cultivada sob densidades de cultivo e poda do pendão floral. Revista Caatinga 26: 9-14.

GUERRA, AMNM; COSTA, ACM; TAVARES, PRF. 2017. Atividade fotossintética e produtividade de alface cultivada sob sombreamento. Revista Agropecuária Técnica 38: 125-132.

HIRATA, ACS; HIRATA, EK. 2015. Desempenho produtivo de agrião d'água cultivado em solo sob telas de sombreamento. Pesquisa Agropecuária Brasileira 50: 895-901.

INMET. Instituto Nacional de Meteorologia. Banco de dados meteorológicos para ensino e pesquisa. 2017. Available http://www.inmet. gov.br/portal/index. php?r=bdmep/bdmep. Accessed October 30, 2019.

KÄMPF, AN. 2000. Seleção de materiais para uso como substrato. In: KÄMPF, AN; FERMINO, MH (eds). Substrato para plantas: a base da produção vegetal em recipientes. Porto Alegre: Gênesis. p.139-145.

KANO, C; CARDOSO, AII; VILLAS BÔAS, RL. 2010. Influência de doses de potássio nos teores de macronutrientes em plantas e sementes de alface. Horticultura Brasileira 28: 287-291.

LARCHER, W. 2000. Ecofisiologia vegetal. São Carlos: RiMa.

MADEIRA, RN; SILVA, PC; BOTREL, N; MENDONÇA, JL; SILVEIRA, GSR; PEDROSA, MW. 2013. Manual de produção de hortaliças tradicionais. Brasília: Embrapa.

MAGGIONI, MS; ROSA, CBCJ; ROSA JUNIOR, EJ; SILVA, EF; ROSA, YBCJ; SCALON, SPQ; VASCONCELOS, AA. 2014. 
Desenvolvimento de mudas de manjericão (Ocimum basilicum L.) em função do recipiente e do tipo e densidade de substratos. Revista Brasileira de Plantas Medicinais 16: 10-17.

MONIRUZZAMAN, M; ISLAM, MS; HOSSAIN, MM; HOSSAIN, T; MIAH, MG. 2009. Effects of shade and nitrogen levels on quality of bngladhonia production. Bangladesh Journal of Agricultural Research 34: 205-213.

MORALES-PAYÁN, JP; BRUNNER, B; FLORES, L; MARTÍNEZ, S. 2013. Culantro Orgánico. Mayguez: Univerdad de Puerto Rico, 11p. (Hoja informativa).

OLIVEIRA, EQ; SOUZA, RJ; CRUZ, MCM; MARQUES, VB; FRANÇA, AC. 2010. Produtividade de alface e rúcula, em sistema consorciado, sob adubação orgânica e mineral. Horticultura Brasileira 28: 36-40.

REIS, LS; SOUZA, JL; AZEVEDO, CAV; LYRA, GB; FERREIRA JÚNIOR, RA; LIMA, VLA. 2012. Componentes da radiação solar em cultivo de tomate sob condições de ambiente protegido. Revista Brasileira de Engenharia Agrícola e Ambiental 16: 739-744.

SILVA, EC; QUEIROZ, RL. 2014. Formação de mudas de alface em bandejas preenchidas com diferentes substratos. Bioscience Journal 30: 725-729.

SILVA, EMNCP; FERREIRA, RLF; RIBEIRO, AMAS; ARAÚJO NETO, SE; KUSDRA, JF. 2015. Desempenho agronômico de alface orgânica influenciado pelo sombreamento, época de plantio e preparo do solo no Acre. Pesquisa Agropecuária Brasileira 50: 468474.

SIMÕES, AC; ALVES, GKEB; FERREIRA, RLF; ARAÚJO NETO, SE. 2015. Qualidade da muda e produtividade de alface orgânica com condicionadores de substrato. Horticultura Brasileira 33: 521-526.

SINGH, S; SINGH, DR; BANU, S; SALIM, KM. 2013. Determination of bioactive and antioxidant activity in Eryngium foetidum L.: a traditional culinary and medicinal herb. Proceedings of the National Academy of Sciences India Section B: Biological Sciences 83: 453-460. SOUSA, DMG; MIRANDA, LN; OLIVEIRA, SA. 2007. Acidez do solo e sua correção. In: NOVAIS, RF; ALVAREZ, VH; BARROS, NF; FONTES, RLF; CANTARUTTI, RB; NEVES, JCL. (eds). Fertilidade do solo. Viçosa: SBCS.

TAIZ, L; ZEIGER, E. 2013. Fisiologia vegetal. 5. ed. Porto Alegre: Artmed.

THOMAS, PS; ESSIEN, EE; NTUK, S; CHOUDHARY, MI. 2017. Eryngium foetidum L. essential oils: chemical composition and antioxidant capacity. Medicines 4.

ZANFIROV,CA; CARPANETTI, MG; CORREA, FF; CARDOSO, AII. 2012. Produção de cenoura em função de doses de potássio em cobertura. Horticultura Brasileira 30: 747-750.

ZORZETO, TQ; DECHEN, SCF; ABREU, MF; FERNANDES JÚNIOR, F. 2014. Caracterização física de substratos para plantas. Bragantia 73: 300-311. 